\title{
The Generation of a 17 kDa Neurotoxic Fragment: An Alternative Mechanism by which Tau Mediates $\beta$-Amyloid-Induced Neurodegeneration
}

\author{
So-Young Park and Adriana Ferreira \\ Department of Cell and Molecular Biology, Feinberg School of Medicine, and Institute for Neuroscience, Northwestern University, Chicago, Illinois 60611
}

Recently, we have shown that the microtubule-associated protein tau is essential for $\beta$-amyloid (A $\beta$ )-induced neurotoxicity in hippocampal neurons. However, the mechanisms by which tau mediates $\mathrm{A} \beta$-induced neurite degeneration remain poorly understood. In the present study, we analyzed whether tau cleavage played a role in these events. Our results showed that pre-aggregated $\mathrm{A} \beta$ induced the generation of a $17 \mathrm{kDa}$ tau fragment in cultured hippocampal neurons. The generation of this fragment was preceded by the activation of calpain-1. Conversely, inhibitors of this protease, but not of caspases, completely prevented tau proteolysis leading to the generation of the $17 \mathrm{kDa}$ fragment and significantly reduced $\mathrm{A} \beta$-induced neuronal death. Furthermore, the expression of this fragment in cultured hippocampal neurons induced the formation of numerous varicosity-bearing tortuous processes, as well as the complete degeneration of some of those neurite processes. These results suggest that $\mathrm{A} \beta$-induced neurotoxicity may be mediated, at least in part, through the calpain-mediated generation of a toxic $17 \mathrm{kDa}$ tau fragment. Collectively, these results provide insight into a novel mechanism by which tau could mediate $\mathrm{A} \beta$-induced neurotoxicity.

Key words: Alzheimer; apoptosis; degeneration; hippocampus; neurotoxicity; proteolysis; amyloid

\section{Introduction}

Alzheimer's disease (AD), the most common cause of dementia in people 65 years and older, is a neurodegenerative disorder characterized by the presence of senile plaques and neurofibrillary tangles (NFTs) in the affected brain areas. Senile plaques are extracellular deposits of $\beta$-amyloid $(\mathrm{A} \beta)$, a proteolytic fragment originated in the amyloid precursor protein (Glenner and Wong, 1984; Yankner and Mesulam, 1991; Selkoe, 1994). NFTs, in contrast, are intracellular aggregates of hyperphosphorylated tau that accumulate both in the perikarya and along axonal and dendritic processes (Kosik et al., 1986; Wood et al., 1986; Kondo et al., 1988). These lesions are both considered pathological hallmarks of $\mathrm{AD}$. However, the relationship between them has not been elucidated completely. Evidence of a direct link between these lesions has been obtained recently (Rapoport et al., 2002). This study showed that neurons expressing either mouse or human tau degenerated in the presence of pre-aggregated $\mathrm{A} \beta$, whereas no signs of degeneration were detected in $\mathrm{A} \beta$-treated taudepleted neurons (Rapoport et al., 2002). Although these results support a key role for tau in $\mathrm{A} \beta$-induced neurodegeneration, the mechanism by which this microtubule-associated protein mediates $\mathrm{A} \beta$ neurotoxicity remains poorly understood. A potential

Received Dec. 8, 2004; accepted April 20, 2005.

This work was supported by National Institutes of Health Grant NS39080 to A.F.

Correspondence should be addressed to Dr. Adriana Ferreira, Institute for Neuroscience, Northwestern Univer-

sity, Searle Building Room 5-474,320 East Superior Street, Chicago, IL 60611.E-mail: a-ferreira@northwestern.edu. D0I:10.1523/JNEUROSCI.1125-05.2005

Copyright $\odot 2005$ Society for Neuroscience $\quad$ 0270-6474/05/255365-11\$15.00/0 link between senile plaques and NFTs involves the A $\beta$-induced activation of putative tau kinases leading to tau phosphorylation. Indeed, tau hyperphosphorylation has been attributed to the increased activity of kinases, such as cyclin-dependent kinase 5 and glycogen synthase kinase- $3 \beta$ or the mitogen-activated protein kinase, in either young or mature hippocampal neurons treated with pre-aggregated $A \beta$, respectively (Takashima et al., 1993; Ferreira et al., 1997; Alvarez et al., 1999; Ekinci et al., 1999). More recently, the potential role for the proteolytic tau cleavage in $\mathrm{A} \beta$-induced neuronal degeneration has been investigated. These studies showed that Glu ${ }^{391}$ truncated tau was present in AD brains but not in age-matched controls (Novak et al., 1993). In addition, the cleavage of tau at Asp ${ }^{421}$ by caspase- 3 has been detected both in neurons treated with pre-aggregated $\mathrm{A} \beta$ and in AD brains (Chung et al., 2001; Gamblin et al., 2003).

In the present study, we performed a series of experiments to further elucidate the role of proteolytic tau cleavage in the mechanisms underlying $\mathrm{A} \beta$-induced neurotoxicity. The results described here provided evidence suggesting that pre-aggregated $\mathrm{A} \beta$ induced the generation of a $17 \mathrm{kDa}$ tau fragment through the activation of calpain-1 in hippocampal neurons. This proteolytic process was completely blocked by calpain inhibitors [ $N$-acetylLeu-Leu-Nle-CHO (ALLN) and carbobenzoxy-valinylphenylalaninal (MDL 28,170)] but not by caspase inhibitors (DEVD and VAD). In addition, calpain inhibitors significantly reduced $\mathrm{A} \beta$-induced neuronal death. Conversely, the expression of this tau fragment led to neurite degeneration and cell death in neurons and in non-neuronal cell types. These results suggest that $\mathrm{A} \beta$-induced neurotoxicity may be mediated, at least in part, 
through the activation of proteases, leading to the generation of the $17 \mathrm{kDa}$ neurotoxic tau fragment in hippocampal neurons.

\section{Materials and Methods}

Preparation of hippocampal cultures. Embryonic day 18 rat embryos were used to prepare hippocampal cultures as described previously (Goslin and Banker, 1990). Briefly, hippocampi were dissected and freed of meninges. The cells were dissociated by trypsinization $(0.25 \%$ for $15 \mathrm{~min}$ at $37^{\circ} \mathrm{C}$ ), followed by trituration with a fire-polished Pasteur pipette. The cell suspension was then plated on poly-L-lysine-coated coverslips in MEM with $10 \%$ horse serum. After $4 \mathrm{~h}$, the coverslips were transferred to dishes containing an astroglial monolayer and maintained in MEM containing N2 supplements (Bottenstein and Sato, 1979) plus ovalbumin $(0.1 \%)$ and sodium pyruvate $(0.1 \mathrm{~mm})$. For biochemical experiments, hippocampal neurons were plated at high density $(500,000$ cells $/ 60 \mathrm{~mm}$ dish) in MEM with 10\% horse serum. After $4 \mathrm{~h}$, the medium was replaced with glia-conditioned MEM containing N2 supplements (Bottenstein and Sato, 1979$)$ plus ovalbumin $(0.1 \%)$ and sodium pyruvate $(0.1 \mathrm{~mm})$.

$A \beta$ aggregation and treatment. Synthetic $\mathrm{A} \beta_{(1-40)}$ (Sigma, St. Louis, $\mathrm{MO}$ ) was dissolved in $\mathrm{N} 2$ medium at $0.5 \mathrm{mg} / \mathrm{ml}$ and incubated for $4 \mathrm{~d}$ at $37^{\circ} \mathrm{C}$ to pre-aggregate the peptide (Ferreira et al., 1997). Pre-aggregated $\mathrm{A} \beta$ was added to the culture medium at a final concentration of $20 \mu \mathrm{M}$. For dose-response experiments, hippocampal neurons kept in culture for $21 \mathrm{~d}$ were incubated for $24 \mathrm{~h}$ with pre-aggregated $\mathrm{A} \beta$ at final concentrations ranging from 0.02 to $20 \mu \mathrm{M}$. For time course experiments, the neurons were grown in the presence of $20 \mu \mathrm{M}$ pre-aggregated $\mathrm{A} \beta$ for 2,4 , 8 , and $24 \mathrm{~h}$.

Protein determination, electrophoresis, and immunoblotting. To prepare heat-stable fractions, cultures were washed twice and scraped in warmed PBS and immediately boiled for $5 \mathrm{~min}$. After centrifugation, the supernatant was diluted 1:1 in Laemmli buffer. To prepare whole-cell extracts, cultures were rinsed twice in warmed PBS, scraped into Laemmli buffer, and homogenized in a boiling water bath for $10 \mathrm{~min}$. The protein concentration was determined by the method of Lowry et al. (1951) as modified by Bensadoun and Weinstein (1976). SDS-polyacrylamide gels were run according to Laemmli (1970). Transfer of protein to Immobilon membrane (Millipore, Bedford, MA) and immunodetection were performed according to Towbin et al. (1979) as modified by Ferreira et al. (1989). The following antibodies were used: anti- $\alpha$-tubulin (clone DM1A; 1:500,000; Sigma), anti-tau [clone tau-5 (LoPresti et al., 1995); 1:1000], anti-dephosphorylated tau (clone tau-1; 1:100,000; Roche Applied Science, Indianapolis, IN), anti-phosphorylated tau (clone AT8; 1:1000; Biosource International, Foster City, CA), anti-tau truncated at Asp $^{421}$ (clone tau-C3; 1:1000; Chemicon, Temecula, CA), anti-90 kDa heat shock protein (Hsp90; clone 68; 1:1000; BD Biosciences, San Diego, CA), anti-caspase-3 (1:1000; Cell Signaling Technology, Beverly, MA), anti-cleaved caspase-3 (1:1000; Cell Signaling Technology), anticalpain-1 (1:5000; Calbiochem, San Diego, CA), and anti-spectrin antibody (1:1000; Chemicon). Secondary antibodies conjugated to horseradish peroxidase (1:1000; Promega, Madison, WI) followed by enhanced chemiluminescence reagents (Amersham Biosciences, Piscataway, NJ) were used for the detection of proteins. Densitometry was performed by using a Bio-Rad (Hercules, CA) 700 flatbed scanner and Molecular Analyst software (Bio-Rad). Films and membranes were scanned at 600 dots per inch by using light transmittance, and pixel volume analysis was performed on the appropriate bands. Densitometric values were normalized using $\alpha$-tubulin or Hsp90 as internal controls. Scanning of the Western blots demonstrated the curve to be linear in the range used for each antibody.

Caspase- 3 activity assay. Caspase- 3 activity was measured using the Fluorometric Caspase-3 Activity Assay kit (Calbiochem) according to the manufacturer's instructions. The fluorescence was measured after cleavage of the caspase-3 substrate (DEVD) labeled with a fluorescent molecule, 7-amino-4-trifluoromethyl coumarin (AFC), to AFC by caspase-3. Briefly, hippocampal neurons cultured for $21 \mathrm{~d}$ were treated with $20 \mu \mathrm{M}$ pre-aggregated $\mathrm{A} \beta$ for up to $24 \mathrm{~h}$. The neurons were harvested in extraction buffer and incubated on ice for $20 \mathrm{~min}$. After centrifugation at $500 \times$ $g$ for $5 \mathrm{~min}$, the supernatant was incubated with the caspase- 3 substrate
(DEVD-AFC) for $2 \mathrm{~h}$ at $37^{\circ} \mathrm{C}$. The fluorescence was assessed using a fluorescent plate reader with a $400 \mathrm{~nm}$ excitation and a $505 \mathrm{~nm}$ emission. The protein concentration was determined by the method of Lowry et al. (1951) as modified by Bensadoun and Weinstein (1976).

Calpain activity assay. Cleavage of the fluorogenic calpain substrate (Suc-Leu-Tyr-AMC; Calbiochem) to its fluorescent product [aminomethylcoumarin (AMC)] was used to measure calpain activity as described previously (Boland and Campbell, 2003). Briefly, 21-d-in-culture hippocampal neurons treated in the presence or absence of the calpain inhibitor ALLN (50 $\mu \mathrm{M}$; Santa Cruz Biotechnology, Santa Cruz, CA) or MDL 28,170 (10 $\mu \mathrm{M}$; Calbiochem) for $1 \mathrm{~h}$ were incubated with preaggregated $\mathrm{A} \beta(20 \mu \mathrm{M})$ for up to $24 \mathrm{~h}$. These neurons were then harvested in lysis buffer ( $25 \mathrm{~mm}$ HEPES, $5 \mathrm{~mm} \mathrm{MgCl}_{2}, 5$ mм DTT, 5 mм EDTA, 2 mM PMSF, and $10 \mu \mathrm{g} / \mathrm{ml}$ pepstatin, $\mathrm{pH} 7.4$ ), subjected to three freezethaw cycles, and centrifuged at $10,000 \times g$ for $10 \mathrm{~min}$ at $4^{\circ} \mathrm{C}$. The supernatant $(90 \mu \mathrm{l})$ was incubated with $10 \mu \mathrm{l}$ of the calpain substrate $(500$ $\mu \mathrm{M})$ for $1 \mathrm{~h}$ at $30^{\circ} \mathrm{C}$. Assay buffer $(100 \mu \mathrm{l} ; 100 \mathrm{~mm}$ HEPES containing 10 mм DTT, pH 7.4) was added, and the fluorescence was assessed measuring excitation at $380 \mathrm{~nm}$ and emission at $480 \mathrm{~nm}$ using a fluorescence plate reader. The protein concentration was determined by the method of Lowry et al. (1951) as modified by Bensadoun and Weinstein (1976).

Protease inhibitor treatment. To inhibit caspase activation, hippocampal neurons kept in culture for $21 \mathrm{~d}$ were pretreated with $50 \mu \mathrm{M} \mathrm{Ac}$ DEVD-CHO (Calbiochem) or $50 \mu \mathrm{M}$ Ac-VAD-CHO (Calbiochem) for $1 \mathrm{~h}$ as described previously (Canu et al., 1998). Hippocampal neurons were then incubated with $20 \mu \mathrm{M}$ pre-aggregated $\mathrm{A} \beta$ for 4 or $8 \mathrm{~h}$.

To inhibit calpain activation, hippocampal neurons kept in culture for $21 \mathrm{~d}$ were pretreated with $50 \mu \mathrm{M}$ ALLN (Santa Cruz Biotechnology) or 10 $\mu \mathrm{M}$ MDL 28,170 (Calbiochem) for $1 \mathrm{~h}$ as described previously (Canu et al., 1998; Boland and Campbell, 2003). Hippocampal neurons were then incubated with pre-aggregated $\mathrm{A} \beta(20 \mu \mathrm{M})$ for 8 or $24 \mathrm{~h}$.

To assess whether calpain inhibitors could prevent $A \beta$-induced neurodegeneration, 21-d-in-culture hippocampal neurons were pretreated with calpain inhibitor ALLN $(50 \mu \mathrm{M})$ or MDL 28,170 $(10 \mu \mathrm{M}) 1 \mathrm{~h}$ before the incubation with pre-aggregated $\mathrm{A} \beta(20 \mu \mathrm{M})$ for 8 or $24 \mathrm{~h}$ as described above. The cells were then fixed with $4 \%$ paraformaldehyde in PBS containing $0.12 \mathrm{M}$ sucrose for $15 \mathrm{~min}$ and rinsed twice in PBS. They were permeabilized in $0.3 \%$ Triton X-100 in PBS for $5 \mathrm{~min}$, rinsed twice in PBS, preincubated in 10\% BSA in PBS for $1 \mathrm{~h}$ at room temperature, and exposed to the neuron-specific tubulin antibody (clone TUJ-1; 1:200) overnight at $4^{\circ} \mathrm{C}$. The next day, the hippocampal neurons were rinsed twice in PBS, incubated with Alexa Fluor 568 anti-mouse IgG (Molecular Probes, Eugene, OR) for $1 \mathrm{~h}$ at $37^{\circ} \mathrm{C}$, rinsed twice in PBS, and mounted on slide glasses. Apoptotic cell death was assessed using the In Situ Cell Death Detection kit, Fluorescein (Roche Applied Science) as described below. Apoptotic cells [terminal deoxynucleotidyl transferase (TdT)mediated biotinylated UTP nick end labeling (TUNEL + ) cells] were counted using a fluorescence microscope (Nikon, Melville, NY) and expressed as a percentage of total cells.

Construction of mutant tau and fragment tau45-230 expression vectors. The plasmid tau-pRC/CMV, which encodes the longest human tau isoform (tau1-441), was obtained from Dr. A. Caceres (Instituto Ferreyra, Cordoba, Argentina). This plasmid was used as a template to generate the mutant tau using the QuikChange Site-Directed Mutagenesis kit (Stratagene, Cedar Creek, TX). One of the known caspase-3 cleavage sites $\left(\mathrm{Asp}^{421}\right.$ ) was mutated to glutamic acid, and two of the possible calpain cleavage sites ( $\mathrm{Leu}^{43}$ and $\mathrm{Val}^{229}$ ) were mutated to alanines using the following oligonucleotide primers: 5'-ATCGACATGGTAGAGTCGCCCCAGCTC- $3^{\prime}$ and $5^{\prime}$-GAGCTGGGGCGACTCTACCATGTCCAT3' $\left(\right.$ Asp $\left.^{421}\right) ;$ 5'-CACGGACGCTGGGCGAAAGAATCTCCCCTG-3' and $5^{\prime}$-CAGGGGAGATTCTTTCGCGCCAGCGTCCGTG-3' (Leu ${ }^{43}$ ); 5'-AGGTGGCAGTGGCCCGTACTCCACC- ${ }^{\prime}$ ' and $5^{\prime}$-GGTGGAGTACGGGCCACTGCCACCT-3' $\left(\mathrm{Val}^{229}\right)$. Mutations were verified by DNA sequencing.

The $17 \mathrm{kDa}$ tau fragment (tau45-230) was prepared by PCR using full-length tau (tau-pRC/CMV) as a template. The following PCR primers containing the EcoRI ( $5^{\prime}$ primer) and BamHI (3' primer) 
restriction sites that enabled insertion into pEGFP-N1 polylinker were used: $5^{\prime}$-GCCCGAATTCATGAAAGAATCTCCCCTGCAGACC-3' (5' primer) and 5'-TTACAGGATCCCGGACCACTGCCACCTTCTT-3' ( $3^{\prime}$ primer).

PCR products were gel purified and cloned into pGEM-T Easy vector (Promega). The amplified vector with insert was digested with EcoRI and BamHI, gel purified, and subcloned into the living colors mammalian expression vector [green fluorescent protein (GFP)] and pcDNA3.1(-) (Invitrogen, Grand Island, NY). PCR was performed using the GeneAmp PCR System 2400 (PerkinElmer, Wellesley, MA). PCR conditions were as follows: $94^{\circ} \mathrm{C}$ for $30 \mathrm{~s}, 64^{\circ} \mathrm{C}$ for $30 \mathrm{~s}$, and $72^{\circ} \mathrm{C}$ for $30 \mathrm{~s}$ for $30 \mathrm{cycles}$, followed by $5 \mathrm{~min}$ at $72^{\circ} \mathrm{C}$. All amplified inserts were confirmed by DNA sequencing.

Cell culture and DNA transfection. Chinese hamster ovary (CHO) cells were grown in F-12 medium plus 10\% fetal bovine serum supplemented with $2 \mathrm{~mm}$ glutamine, 100 international units $/ \mathrm{ml}$ penicillin, and 100 $\mu \mathrm{g} / \mathrm{ml}$ streptomycin. CHO cells were transfected with tau-pRC/CMV, D421E-tau-pRC/CMV, L43A-V229A-tau-pRC/CMV, or tau45-230pcDNA3.1(-) using LipofectAMINE according to the manufacturer's instructions (Invitrogen). Briefly, cells were subcultured to a density of $2 \times 10^{5}$ cells/well in $35 \mathrm{~mm}$ dishes. The next day, $2 \mu \mathrm{g}$ of DNA was incubated with $5 \mu \mathrm{l}$ of LipofectAMINE at room temperature in the dark for $30 \mathrm{~min}$ to form the DNA-lipid complex. Cells were then incubated with DNA-lipid complex for $48 \mathrm{~h}$.

Tau in vitro cleavage assay by caspase- 3 and calpain-1. CHO cells were transfected with tau-pRC/CMV or D421E-tau-pRC/CMV. Forty-eight hours later, the cells were washed three times in PBS, scraped in lysis buffer (20 mm Tris-HCl, pH 7.4, $150 \mathrm{~mm} \mathrm{NaCl}, 1 \mathrm{~mm}$ dithiothreitol, $5 \mathrm{~mm}$ EDTA, 5 mm EGTA, and 1\% Triton X-100), and incubated on ice for $1 \mathrm{~h}$. Cell lysates were then centrifuged for $10 \mathrm{~min}$ at $16,000 \times \mathrm{g}$, and the supernatants were stored at $-20^{\circ} \mathrm{C}$ until use. The supernatants $(10 \mu \mathrm{l})$ were then incubated in the presence or absence of recombinant caspase- 3 $(0.3 \mu \mathrm{g} / \mu \mathrm{l})$ in caspase- 3 buffer for $60 \mathrm{~min}$ at $37^{\circ} \mathrm{C}$, as described previously (Brancolini et al., 1997; Estus et al., 1997). The reactions were terminated by adding 1 vol of $2 \times$ SDS sample buffer and boiled for 10 min. Samples were subjected to Western blot analysis using tau antibodies.

$\mathrm{CHO}$ cells were also transfected with tau-pRC/CMV, L43A-V229Atau-pRC/CMV, or tau45-230-pcDNA3.1 ( - ) for $48 \mathrm{~h}$. After three washes in PBS, cells were lysed in lysis buffer for $1 \mathrm{~h}$ at $0^{\circ} \mathrm{C}$. The cell lysates were cleared by centrifugation and stored at $-20^{\circ} \mathrm{C}$ until use. Sixteen microliters of the cell lysates were incubated in the presence or absence of calpain- $1(0.25 \mathrm{U})$ for $1 \mathrm{~h}$ at $30^{\circ} \mathrm{C}$. The digestion reaction was stopped by adding 1 vol of $2 \times$ SDS sample buffer and boiled for $10 \mathrm{~min}$. Samples were subjected to Western blot analysis using a tau antibody.

Immunocytochemistry and TUNEL assay. Fourteen-day-in-culture hippocampal neurons were transfected with 17Tau-GFP (tau45-230GFP), Tau-GFP (full-length tau-GFP), or GFP (empty vector) using LipofectAMINE 2000 according to the manufacturer's instructions to assess the potential neurotoxicity of 17 Tau-GFP. Briefly, hippocampal neurons were equilibrated in $600 \mu \mathrm{l}$ of transfection medium [50\% feeding medium (N2) and 50\% h-medium (MEM plus $10 \mathrm{~mm}$ HEPES)] for $1 \mathrm{~h}$ and incubated in the presence of DNA complexes ( $3 \mu \mathrm{g}$ of DNA with $6 \mu \mathrm{l}$ of LipofectAMINE 2000 in $50 \mu \mathrm{l}$ of h-medium kept at room temperature for $15 \mathrm{~min}$ ) for $1 \mathrm{~h}$ at $37^{\circ} \mathrm{C}$. The coverslips were returned to the original dishes. After 24 or $48 \mathrm{~h}$, cells were fixed for $15 \mathrm{~min}$ in $4 \%$ paraformaldehyde in PBS containing $0.12 \mathrm{M}$ sucrose, permeabilized in $0.3 \%$ Triton X-100 for 5 min, and stained with an FITC-GFP antibody.

Apoptotic cell death was assessed using the In Situ Cell Death Detection kit, TMR Red (Roche Applied Science). Briefly, cells were fixed for 15 min with $4 \%$ paraformaldehyde in PBS containing $0.12 \mathrm{M}$ sucrose and permeabilized in $0.1 \%$ Triton X-100 in $0.1 \%$ sodium citrate for $2 \mathrm{~min}$, and TMR Red-labeled nucleotide was incorporated at $33^{\prime}-\mathrm{OH}$ DNA ends using the enzyme TdT. Apoptotic cells (TUNEL+ cells) were counted using a fluorescence microscope (Nikon) and expressed as a percentage of transfected cells.
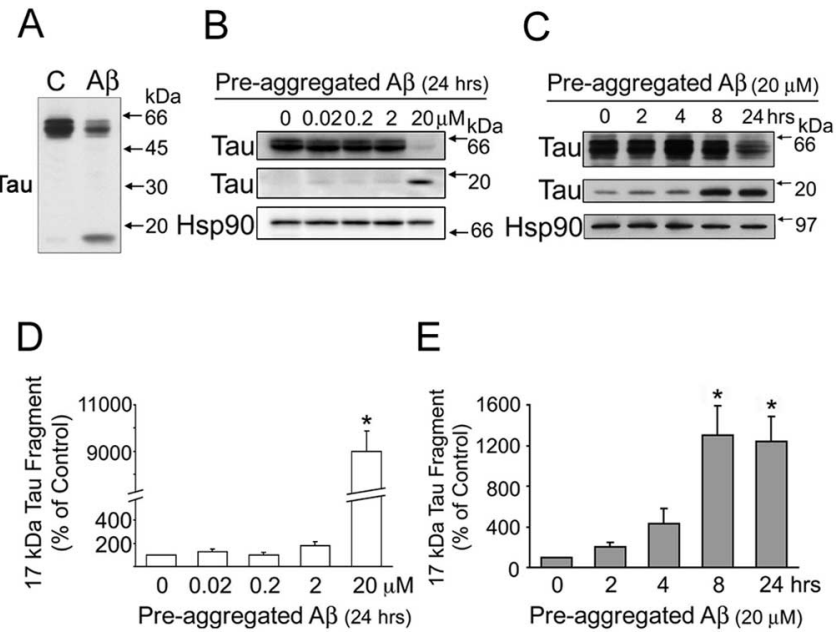

Figure 1. Pre-aggregated $A \beta$ induced tau cleavage in mature hippocampal neurons in a dose- and time-dependent manner. $\boldsymbol{A}$, Western blot analysis of tau content in heat-stable fractions prepared from $21 \mathrm{~d}$ in vitro hippocampal neurons cultured in the absence $(C)$ or in the presence of pre-aggregated $A \beta(20 \mu \mathrm{m})$ for $24 \mathrm{~h}$ using a phosphorylation-independent tau antibody (clone tau-5). Note the decrease in full-length tau and the appearance of a tauimmunoreactive band of $\sim 17 \mathrm{kDa}$ in $A \beta$-treated neurons. $\boldsymbol{B}$, Western blot analysis of tau content in heat-stable fractions prepared from $21 \mathrm{~d}$ in vitro hippocampal neurons cultured for $24 \mathrm{~h}$ in the presence of pre-aggregated $A \beta$ at final concentrations ranging from 0.02 to $20 \mu \mathrm{m}$ using a tau antibody (clone tau-5). C, Western blot analysis of heat-stable fractions prepared from $21 \mathrm{~d}$ in vitro hippocampal neurons cultured in the presence of pre-aggregated $\mathrm{A} \beta(20 \mu \mathrm{m})$ for up to $24 \mathrm{~h}$ using a tau antibody (clone tau-5). Equal amounts of protein were loaded in each lane. The Hsp90 was also used as a loading control. D, E, Graphs showing the levels of the $17 \mathrm{kDa}$ tau fragment in the dose-response $(\boldsymbol{D})$ and time course $(\boldsymbol{E})$ experiments performed as described above. Data were obtained using Molecular Analyst software and normalized using full-length tau and $\mathrm{Hsp} 90$ as internal controls. Values are expressed as a percentage of untreated controls, considering the values obtained in these neurons as $100 \%$. Each number represents the mean \pm SEM from three different experiments. ${ }^{*} p<0.01$, different from control.

\section{Results}

Pre-aggregated $\mathrm{A} \beta$ induced tau cleavage in a dose- and time-dependent manner in mature hippocampal neurons

The mechanisms by which tau mediates $\mathrm{A} \beta$-induced neurotoxicity are not completely elucidated. Recently, it has been shown that the proteolytic cleavage of tau accompanied cell death associated with the deposition of $\mathrm{A} \beta$ in immature cortical neurons (Gamblin et al., 2003). However, no information is available regarding tau cleavage or the proteases involved in this cleavage in mature central neurons. To gain insights into such a process, we first studied whether $A \beta$ induced changes in tau content in cultured hippocampal neurons. We have chosen this model system because the hippocampus is one of the most affected brain regions in $\mathrm{AD}$. In addition, when kept in culture for $>3$ weeks, hippocampal neurons reproduce the functional characteristic and the molecular composition (including the expression of adult, mostly dephosphorylated, tau isoforms) of the ones that develop in vivo (Ferreira et al., 1997). In our first set of experiments, 21-d-in-culture hippocampal neurons were incubated in the presence of pre-aggregated $\mathrm{A} \beta(20 \mu \mathrm{M})$ for $24 \mathrm{~h}$. The cells were then scraped, and heat-stable fractions were prepared. Western blot analysis of tau content in these fractions was performed using a phosphorylation-independent tau antibody [clone tau-5 (LoPresti et al., 1995)]. Pre-aggregated A $\beta$ significantly decreased $(\sim 50 \%)$ full-length tau immunoreactivity in $\mathrm{A} \beta$-treated hippocampal neurons compared with untreated controls (Fig. 1A). In addition, a low-molecular weight tauimmunoreactive band $(\sim 17 \mathrm{kDa})$ was readily detectable in pre- 
aggregated $\mathrm{A} \beta$-treated hippocampal neurons (Fig. 1A). No comparable band was detected in nontreated controls (Fig. $1 A)$. We next investigated whether the effect of pre-aggregated $A \beta$ on the generation of this $17 \mathrm{kDa}$ tau fragment was dose and/or time dependent. For these experiments, 21-d-in-culture hippocampal neurons were incubated for $24 \mathrm{~h}$ with preaggregated $\mathrm{A} \beta$ at final concentrations ranging from 0.02 to $20 \mu \mathrm{M}$. Western blot analysis of heat-stable fractions prepared from these cells revealed the presence of the $17 \mathrm{kDa}$ tau fragment even in cells treated with the lowest dose used in this study. However, the levels of the $17 \mathrm{kDa}$ tau fragment in hippocampal neurons treated with pre-aggregated $\mathrm{A} \beta$ at final concentrations below $2 \mu \mathrm{M}$ were not significantly different from the ones observed in nontreated controls. In contrast, the $17 \mathrm{kDa}$ tau fragment levels were significantly increased in hippocampal neurons treated with $20 \mu \mathrm{M}$ pre-aggregated $\mathrm{A} \beta$ (Fig. $1 B, D$ ). In view of these data, we analyzed the time course of the generation of the $17 \mathrm{kDa}$ tau fragment in neurons treated with preaggregated $\mathrm{A} \beta$ at this final concentration. For these experiments, 21-d-in-culture hippocampal neurons were treated with preaggregated $\mathrm{A} \beta(20 \mu \mathrm{M})$ for up to $24 \mathrm{~h}$, and the presence of cleaved tau was assessed by immunoblotting. The levels of the $17 \mathrm{kDa}$ tau fragment were significantly increased as early as $8 \mathrm{~h}$ after the addition of pre-aggregated $\mathrm{A} \beta$ and continued to increase in a time-dependent manner up to $24 \mathrm{~h}$ (Fig. 1C,E). The levels of 17 $\mathrm{kDa}$ tau fragments remained elevated even in hippocampal neurons treated with pre-aggregated $\mathrm{A} \beta$ for $36 \mathrm{~h}$ compared with nontreated controls (data not shown).

\section{Pre-aggregated A $\beta$-induced tau cleavage preceded tau phosphorylation in cultured hippocampal neurons}

We next compared the time course of tau cleavage described above with the one of tau phosphorylation in cultured hippocampal neurons. For these experiments, hippocampal neurons were treated with pre-aggregated $\mathrm{A} \beta$ for up to $24 \mathrm{~h}$, and heatstable fractions were prepared. Western blot analysis preformed using a tau antibody that recognizes tau phosphorylated at Ser ${ }^{193}$ and $\mathrm{Thr}^{196}$ (AT8) showed no increase in full-length tau phosphorylation at 2, 4, or $8 \mathrm{~h}$ after the addition of pre-aggregated $\mathrm{A} \beta$. In contrast, a significant increase in AT8 immunoreactivity was observed in hippocampal neurons treated with pre-aggregated $\mathrm{A} \beta$ for $24 \mathrm{~h}$ compared with nontreated controls (Fig. $2 A, B$ ). These results are in agreement with previous results showing the increase in tau phosphorylation under these experimental conditions using antibodies directed to different tau phosphoepitopes (Ferreira et al., 1997). In contrast, the $17 \mathrm{kDa}$ tau fragment was not detected using antibodies directed to phosphorylated tau despite the presence of the fragment as early as $8 \mathrm{~h}$ after the addition of pre-aggregated $\mathrm{A} \beta$ (Fig. $1 C$ ). These results suggested that this tau fragment was dephosphorylated in these residues. To test this hypothesis, we confirmed the presence of this $17 \mathrm{kDa}$ tau fragment in pre-aggregated $\mathrm{A} \beta$-treated hippocampal neurons using a tau antibody directed to the same epitope recognized by AT8, but in its dephosphorylated form [clone tau-1 (Szendrei et al., 1993)]. As expected, an intense tau-1-immunoreactive band was detected $8 \mathrm{~h}$ after the addition of pre-aggregated $\mathrm{A} \beta$ in mature hippocampal neurons (Fig. $2 A, C$ ).
B

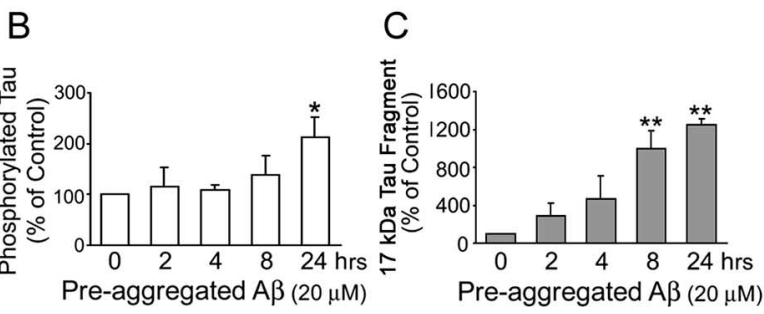

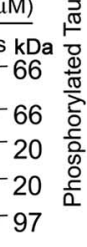

(1)

Figure 2. Pre-aggregated $A \beta$-induced tau cleavage preceded the increase in tau phosphorylation. $\boldsymbol{A}$, Western blot analysis of (1) fractions prepared from 21-d-in-culture hippocampal neurons treated with pre-aggregated $A \beta$ (20 protein were loaded in each lane. $B, C, G$ raphs showing the time course of tau phosphorylation and tau cleavage in the presence of pre-aggregated $A \beta$. Densitometric values were normalized using full-length tau (tau-5) and the Hsp90 as internal controls. Values are expressed as a percentage of untreated controls, considering the values obtained in these neurons as 100\%. Each \pm SEM from three different experiments. ${ }^{*} p<0.05,{ }^{* *} p<0.01$, different from control.

\section{Pre-aggregated A $\beta$ activated caspase- 3 and calpain-1 in mature hippocampal neurons}

Tau contains consensus sequences for cleavage by caspase- 3 and calpain, two proteases that seem to play a role in the pathogenesis of AD (Saito et al., 1993; Rohn et al., 2001; Su et al., 2001;Veeranna et al., 2004). However, no information is available regarding the activation of these proteases in our model system. To obtain this information, we first determined the activity of caspase- 3 and calpain in 21-d-in-culture hippocampal neurons incubated in the presence of pre-aggregated $A \beta$ for up to $24 \mathrm{~h}$. Immunoblots of whole-cell extracts prepared from these cultures were reacted with antibodies that recognized either uncleaved caspase-3 (total caspase-3) or its cleaved form (active caspase-3). Active caspase- 3 levels were significantly higher in pre-aggregated $\mathrm{A} \beta$-treated neurons as early as $4 \mathrm{~h}$ after the addition of this peptide compared with untreated controls (Fig. 3A,B). Active caspase-3 levels remained elevated throughout the rest of the period analyzed (Fig. $3 A, B)$.

We then determined whether the treatment with preaggregated $\mathrm{A} \beta$ also activated calpains in cultured hippocampal neurons. Calpains, a family of calcium-dependent cystein proteases that exist as pro-enzymes in resting cells, are activated by calcium and autolytic processing. Autolysis of the N-terminal region of domain I of calpain leads to the generation of two active proteases of 78 and $76 \mathrm{kDa}$, respectively. Additional autocatalytic processing of domain IV of this protease leads to the generation of a $58 \mathrm{kDa}$ active form (Zimmerman and Schlaepfer, 1984; Imajoh et al., 1987; Mellgren and Murachi, 1990). To assess calpain activity, we stripped the membranes used to determine the activation of caspase- 3 and reprobed them using a calpain antibody that recognizes both calpains. Active calpain $(58 \mathrm{kDa})$ levels were significantly increased $8 \mathrm{~h}$ after the addition of pre-aggregated $\mathrm{A} \beta$ to mature hippocampal neurons compared with untreated controls (Fig. $3 C, D$ ). An increase in active calpain levels was also detected in hippocampal neurons treated with pre-aggregated $\mathrm{A} \beta$ for $24 \mathrm{~h}$. However, these levels were lower than the ones observed $16 \mathrm{~h}$ earlier (Fig. 3C,D). Calpain activation in $\mathrm{A} \beta$-treated hippocampal neurons was also determined by analyzing spectrin cleavage. Calpain-mediated cleavage of spectrin leads to the generation of a specific $150 \mathrm{kDa}$ cleavage product (Veeranna et al., 2004). Quantitative immunoblot analysis revealed that the generation of this $150 \mathrm{kDa}$ spectrin cleavage product was significantly increased $8 \mathrm{~h}$ after the treatment with pre-aggregated $\mathrm{A} \beta$ compared with untreated controls (Fig. $3 C, E$ ). The time course and extent of calpain activation detected using this method were 
A

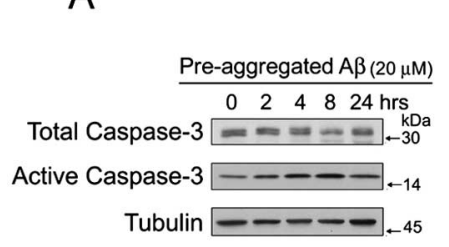

C

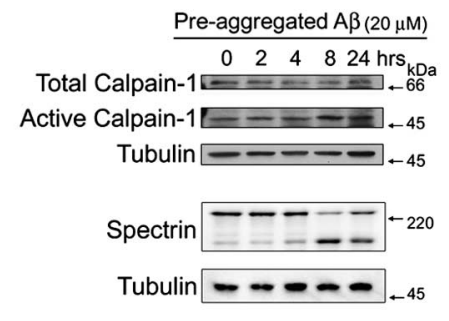

B

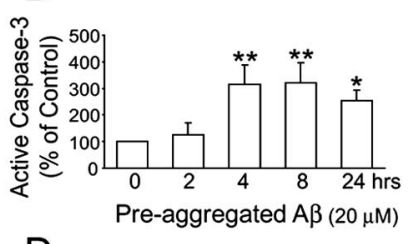

D

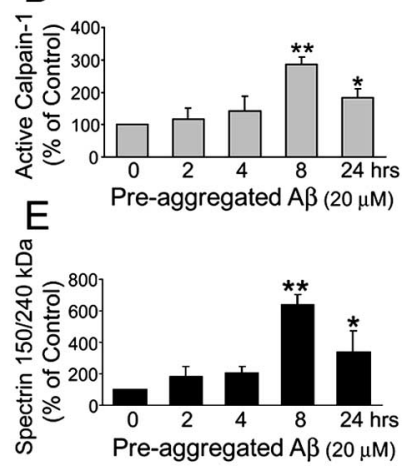

Figure 3. Pre-aggregated $A \beta$ induced the activation of caspase- 3 and calpain- 1 in cultured hippocampal neurons. $\boldsymbol{A}, \boldsymbol{C}$, Western blot analysis of active caspase-3 $(\boldsymbol{A})$ and active calpain-1 (C) content in whole-cell extracts prepared from $21 \mathrm{~d}$ in vitro hippocampal neurons cultured in the presence of pre-aggregated $A \beta$ ( $20 \mu \mathrm{m})$ for up to $24 \mathrm{~h}$ using specific antibodies. Tubulin immunoblots were used as loading controls $(\boldsymbol{B}, \boldsymbol{D}, \boldsymbol{E})$. The bar graphs show the levels of active caspase-3 $(\boldsymbol{B})$, active calpain-1 (D), and calpain-specific cleavage products of spectrin $(\boldsymbol{E})$ in the samples obtained as described above. Note the increase in active calpain-1 levels in samples obtained $8 \mathrm{~h}$ after the addition of $A \beta$ and the concomitant decrease in full-length spectrin and increase in the $150 \mathrm{kDa}$ specific spectrin cleaved product $(\boldsymbol{C}-\boldsymbol{E})$. Densitometric values from active caspase-3, active calpain-1, and cleaved spectrin were normalized using total caspase-3, calpain-1, and full-length spectrin as internal controls. Values are expressed as a percentage of untreated controls, considering the values obtained in these neurons as 100\%. Each number represents the mean \pm SEM from three different experiments. ${ }^{*} p<0.05$, ${ }^{* *} p<0.01$, different from control.

Table 1. Activation of caspase- 3 and calpain by pre-aggregated $A \beta$ in cultured hippocampal neurons

\begin{tabular}{lllll}
\hline \multirow{2}{*}{$\begin{array}{l}\text { Activity of } \\
\text { proteases }\end{array}$} & \multicolumn{4}{l}{ Pre-aggregated $\mathrm{A} \beta(20 \mu \mathrm{m})$} \\
\cline { 2 - 5 } & $2 \mathrm{~h}$ & $4 \mathrm{~h}$ & $8 \mathrm{~h}$ & $24 \mathrm{~h}$ \\
\hline Caspase-3 & $122 \pm 18$ & $154 \pm 11^{* *}$ & $127 \pm 4^{*}$ & $113 \pm 14$ \\
Calpain & $81 \pm 17$ & $83 \pm 27$ & $163 \pm 20^{*}$ & $118 \pm 25$ \\
\hline
\end{tabular}

In vitro protease activity assays were performed using cell extracts obtained from 21-d-in-culture hippocampal neurons incubated in the presence of pre-aggregated $A \beta$ from 2 to $24 \mathrm{~h}$. Values are expressed as a percentage of untreated controls, considering the values obtained in these neurons as $100 \%$. The numbers represent the means \pm SEM obtained from three experiments. ${ }^{*} p<0.05,{ }^{* *} p<0.01$, different from control.

similar to the ones detected by quantifying the $58 \mathrm{kDa}$ active calpain isoform (Fig. 3C,D).

To confirm the results described above, we analyzed the activation of these proteases in pre-aggregated $\mathrm{A} \beta$-treated neurons using in vitro caspase- 3 and calpain assays. The activity of caspase-3 was determined in 21-d-in-culture hippocampal neurons treated with pre-aggregated $\mathrm{A} \beta$ for up to $24 \mathrm{~h}$ by measuring the fluorescence emitted after the cleavage of substrates to AFC by active caspase-3. As determined by Western blot analysis, caspase-3 activity was significantly increased in hippocampal neurons as early as $4 \mathrm{~h}$ after the addition of the peptide (Table 1 ). In vitro assays also confirmed the activation of calpain in cultured hippocampal neurons treated with pre-aggregated $A \beta$. For these experiments, hippocampal neurons treated with pre-aggregated $\mathrm{A} \beta$ for up to $24 \mathrm{~h}$ were harvested in lysis buffer, and the supernatants were incubated with a calpain substrate (Suc-LLVY-AMC) for $1 \mathrm{~h}$ at $30^{\circ} \mathrm{C}$. The fluorescence emitted after the cleavage of the substrate to AMC by active calpains was measured using a fluorescence plate reader. Calpain activity was significantly higher in cultured hippocampal neurons incubated with pre-aggregated $\mathrm{A} \beta$ for $8 \mathrm{~h}$ compared with untreated controls (Table 1).

Protease inhibitors prevented pre-aggregated $\mathrm{A} \beta$-induced tau cleavage in cultured hippocampal neurons

To obtain insights into the role of caspase- 3 and calpain in preaggregated $\mathrm{A} \beta$-induced tau cleavage leading to the generation of the $17 \mathrm{kDa}$ fragment, we blocked the activation of these proteases using specific inhibitors. For these experiments, hippocampal neurons kept in culture for $21 \mathrm{~d}$ were incubated in the presence of Ac-VAD-CHO (an inhibitor of caspase- 3 and, to a lesser extent, caspases-1, -4, and -7) or Ac-DEVD-CHO (a specific caspase-3 inhibitor) and ALLN (a calpain inhibitor) $1 \mathrm{~h}$ before the addition of pre-aggregated $\mathrm{A} \beta(20 \mu \mathrm{M})$. The cells were scraped up to $24 \mathrm{~h}$ later, and whole-cell extracts were analyzed by Western blot using caspase-3, calpain, and tau antibodies. Both VAD and DEVD blocked the activation of caspase- 3 induced by pre-aggregated $\mathrm{A} \beta 4$ and $8 \mathrm{~h}$ after the addition of the peptide (Fig. $4 A, B$ ). In addition, $\mathrm{VAD}$ significantly reduced the generation of the $17 \mathrm{kDa}$ tau fragment in the pre-aggregated $A \beta$-treated cells. On the other hand, DEVD failed to prevent the generation of this tau fragment $8 \mathrm{~h}$ after the addition of pre-aggregated $\mathrm{A} \beta$ (Fig. $4 A, C$ ). In contrast, ALLN completely prevented both the activation of calpain, detected by either the increase in the $58 \mathrm{kDa}$ active calpain- 1 or the $150 \mathrm{kDa}$ calpain-cleaved spectrin products, and the generation of this tau fragment in $\mathrm{A} \beta$-treated hippocampal neurons (Fig. $5 A, C, E, G$ ). Because ALLN is not only a calpain inhibitor but also a proteasome inhibitor, we repeated these experiments using a more specific calpain inhibitor (MDL 28,170). Mature hippocampal neurons were pretreated with MDL 28,170 for $1 \mathrm{~h}$ and incubated with pre-aggregated $\mathrm{A} \beta$ for 8 or $24 \mathrm{~h}$. Immunoblots reacted with the calpain, spectrin, and tau antibodies showed that MDL 28,170 completely inhibited both the activation of calpain and the generation of the $17 \mathrm{kDa}$ tau fragment induced by pre-aggregated $\mathrm{A} \beta$ (Fig. $5 B, D, F, H$ ). Next, we determined whether the incubation of hippocampal neurons with these calpain inhibitors before the addition of pre-aggregated $\mathrm{A} \beta$ prevented the activation of this protease as detected by in vitro assays. For these experiments, calpain inhibitor (ALLN, MDL 28,170 )-treated hippocampal neurons were incubated with preaggregated $A \beta$ for $8 \mathrm{~h}$. The neurons were then scraped in lysis buffer, and the supernatants were incubated with a calpain substrate (Suc-LLVY-AMC) for $1 \mathrm{~h}$ at $30^{\circ} \mathrm{C}$. The fluorescence emitted after the cleavage of the substrate to AMC by active calpain was measured using a fluorescence plate reader. Calpain activity was significantly lower in calpain inhibitor-treated neurons incubated with pre-aggregated $\mathrm{A} \beta$ compared with neurons treated with pre-aggregated $A \beta$ alone (Table 2).

\section{Calpain, but not caspase-3, cleaved tau, generating a $17 \mathrm{kDa}$ fragment in vitro}

To obtain more direct information regarding the proteases involved in the generation of the $17 \mathrm{kDa}$ tau fragment in cultured hippocampal neurons treated with pre-aggregated $\mathrm{A} \beta$, we performed a series of in vitro tau cleavage assays. For these experiments, $\mathrm{CHO}$ cells were transfected with the full-length tau plasmid (tau-pRC/CMV) and a tau plasmid (D421E-tau-pRC/CMV) with a point mutation (from Asp to Glu) at position 421 to prevent its cleavage by caspase- 3 . Whole-cell extracts were prepared and treated with recombinant caspase- 3 for $1 \mathrm{~h}$ at $37^{\circ} \mathrm{C}$. As shown in Figure 6 $\mathrm{A}$, caspase-3 did cleave full-length tau but not D421E- 
tau. The cleavage of tau at $\mathrm{Asp}^{421}$ by caspase- 3 was confirmed using a tau antibody that recognizes the Asp ${ }^{421}$ cleavage site (clone tau-C3). However, caspase-3 cleavage failed to generate a $17 \mathrm{kDa}$ tau fragment as the one observed in hippocampal neurons cultured in the presence of pre-aggregated $\mathrm{A} \beta$ (Fig. 6A). To determine whether calpain cleavage was able to generate such a tau fragment, we transfected $\mathrm{CHO}$ cells with the tau-pRC/ CMV or L43A-V229A-tau-pRC/CMV plasmids. From the nine potential calpain cleavage sites, only the cleavage at residues 45 and 230 could generate the $17 \mathrm{kDa}$ tau fragment. Therefore, these residues (Leu43 and Val229) were point-mutated to Ala. CHO cells transfected with the taupRC/CMV or L43A-V229A-tau-pRC/ CMV plasmid were harvested in lysis buffer and incubated on ice for $1 \mathrm{~h}$. Supernatants following the centrifugation were incubated with calpain- 1 for $1 \mathrm{~h}$ at $30^{\circ} \mathrm{C}$. Incubation of full-length tau with calpain-1 generated a tau-immunoreactive band of $\sim 17 \mathrm{kDa}$, identical to that seen in neurons treated with pre-aggregated $\mathrm{A} \beta$ for $24 \mathrm{~h}$. In contrast, the digestion of point-mutated tau at 43 and 229 positions by calpain-1 failed to generate such a band (Fig. $6 B)$. To determine whether the $17 \mathrm{kDa}$ tau fragment was further degraded by calpain or whether it was the final cleavage product, the tau45-230-pcDNA3.1(-) plasmid was transfected to $\mathrm{CHO}$ cells and the lysates were treated with calpain for $1 \mathrm{~h}$ at $30^{\circ} \mathrm{C}$. The incubation of lysates with calpain did not generate additional fragments, suggesting that the $17 \mathrm{kDa}$ tau fragment was not further degraded by calpain (Fig. 6C).

\section{The $17 \mathrm{kDa}$ Tau fragment had toxic effects both in CHO cells and cultured hippocampal neurons}

To assess the potential toxic effects of the $17 \mathrm{kDa}$ tau fragment, we transfected the tau45-230-GFP (17Tau-GFP) plasmid into $\mathrm{CHO}$ cells using LipofectAMINE. CHO cells transfected with the GFP (empty vector) were used as controls. CHO cells were fixed $48 \mathrm{~h}$ after transfection, and DNA fragmentation was examined using a TUNEL assay. Most of the cells transfected with GFP (empty vector) were TUNEL-. No differences in the number of TUNEL + cells were detected in GPF-transfected CHO cells compared with nontransfected ones. In contrast, a significantly higher number $(>35 \%)$ of TUNEL + cells were detected in 17Tau-GFP-transfected CHO cells compared with GFP (empty vector)-transfected and/or nontransfected cells (Fig. 7).

The experiments described above suggested that the $17 \mathrm{kDa}$ tau fragment had toxic effects in $\mathrm{CHO}$ cells. To test whether this tau fragment also played a role in neurodegeneration, hippocampal neurons cultured for $14 \mathrm{~d}$ were transfected with 17Tau-GFP using LipofectAMINE 2000. Transfections using full-length TauGFP or GFP (empty vector) were used as controls. No changes in morphology or cell survival were detected in hippocampal neurons transfected with either full-length Tau-GFP or GFP (empty vector) 24 and $48 \mathrm{~h}$ after the transfection (Fig. 8). No morphological changes were detected either in $17 \mathrm{kDa}$ tau-transfected neurons $24 \mathrm{~h}$ after the transfection. In contrast, apparent signs of degeneration were detected $48 \mathrm{~h}$ after hippocampal neurons were transfected with 17Tau-GFP (Fig. 8). These signs included the formation of tortuous processes, the presence of varicosities along the neurites, and the retraction of neuritic processes.
Calpain inhibitors prevented $\mathrm{A} \boldsymbol{\beta}$-induced neurodegeneration in cultured hippocampal neurons

Finally, we analyzed whether calpain inhibitors block $\mathrm{A} \beta$ induced neurotoxicity in cultured hippocampal neurons. For these experiments, 21-d-in-culture hippocampal neurons treated with calpain inhibitors, ALLN (50 $\mu \mathrm{M})$ or MDL 28,170 (10 $\mu \mathrm{M})$, were incubated with pre-aggregated $\mathrm{A} \beta(20 \mu \mathrm{M})$. Neuronal morphology was analyzed $24 \mathrm{~h}$ later. The signs of neurodegeneration described above were readily observed in hippocampal neurons treated with pre-aggregated $\mathrm{A} \beta$ for $24 \mathrm{~h}$ (Fig. $9 B$ ). In contrast, they were not detectable in untreated controls or in neurons treated with calpain inhibitors before the treatment with preaggregated $\mathrm{A} \beta$ (Fig. $9 A, C, D$ ). We also assessed the effect of calpain inhibitors on neuronal cell death induced by pre-aggregated $\mathrm{A} \beta$. For these experiments, DNA fragmentation was examined using TUNEL assay. Although only a few hippocampal neurons $(20 \pm 1 \%)$ were TUNEL + in untreated controls, more than onehalf of the neurons $(60 \pm 4 \%)$ were TUNEL + in pre-aggregated $\mathrm{A} \beta$-treated cultures. In contrast, the number of TUNEL + hippocampal neurons treated with calpain inhibitors, ALLN or MDL 28,170 , before pre-aggregated $\mathrm{A} \beta$ for 24 h was significantly decreased ( $30 \pm 2$ and $27 \pm 1 \%$, respectively) compared with neurons treated with $\mathrm{A} \beta$ in the absence of calpain inhibitors (Fig. 9E).

\section{Discussion}

The results presented here indicated that pre-aggregated $\mathrm{A} \beta$ induced tau proteolysis, leading to the generation of a neurotoxic $17 \mathrm{kDa}$ tau fragment in hippocampal neurons. In addition, they suggested that the production of this fragment was the result of the $\mathrm{A} \beta$-induced activation of calpain in these neurons. Furthermore, the inhibition of calpain activation using specific calpain inhibitors prevented $\mathrm{A} \beta$-induced neurodegeneration in cultured hippocampal neurons. Together, these data provided insights into a novel mechanism by which tau could mediate, at least in part, $\mathrm{A} \beta$-induced neurotoxicity in hippocampal neurons.

A consensus exists regarding the toxic effects of preaggregated $\mathrm{A} \beta$ in neurons that develop in situ and in culture (Flood et al., 1991; Nitta et al., 1994; Busciglio et al., 1995; Copani et al., 1995; Estus et al., 1997). However, the mechanisms by which pre-aggregated $A \beta$ exerts its toxic effects in the CNS remain poorly understood. Oxidative stress, mitochondrial dysfunction, disturbances of calcium homeostasis, and microglial activation have already been identified as mediators of $\mathrm{A} \beta$ toxicity (for review, see Canevari et al., 2004). In addition, the role of multiple potential downstream elements of the signaling path- 
A

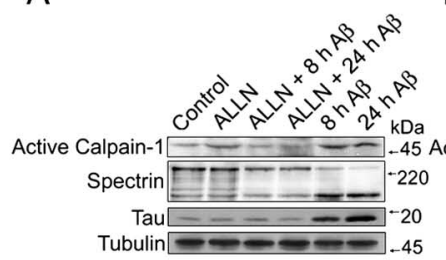

B

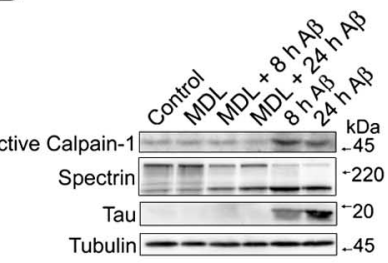

C

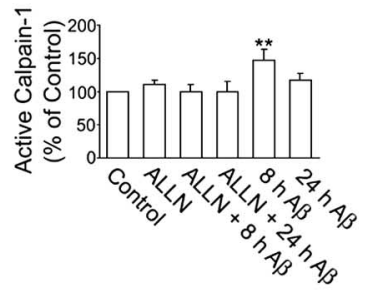

D

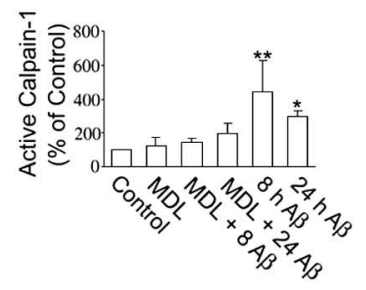

$\mathrm{E}$

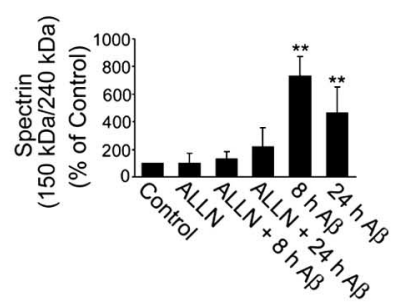

G

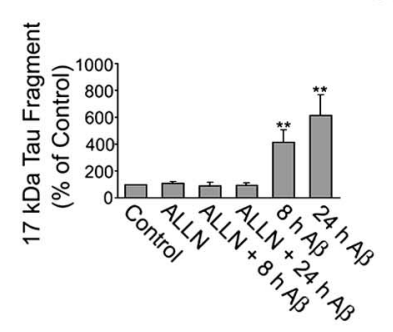

$\mathrm{H}$
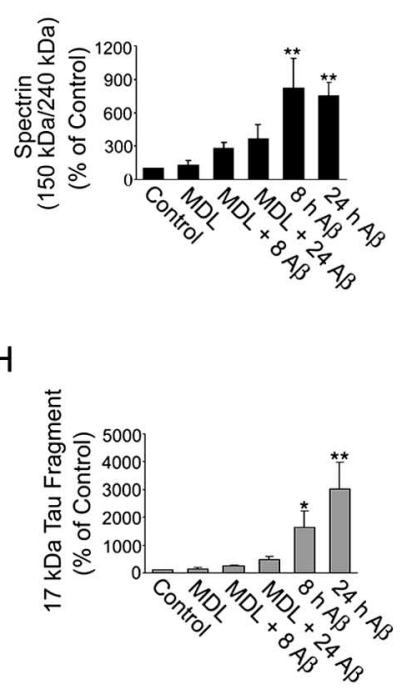

Figure 5. Calpain inhibitors completely blocked the generation of the $17 \mathrm{kDa}$ tau fragment induced by pre-aggregated $A \beta$ in cultured hippocampal neurons. $A, B$, Western blot analysis of active calpain-1, cleaved spectrin, and $17 \mathrm{kDa}$ tau fragment content in whole-cell extracts prepared from 21-d-in-culture hippocampal neurons treated with either ALLN $(A)$ or MDL $28,170(B)$, two calpain inhibitors, $1 \mathrm{~h}$ before the treatment with pre-aggregated $\mathrm{A} \beta(20 \mu \mathrm{M})$ for 4 and $8 \mathrm{~h}$ using specific antibodies. $\mathbf{C} \boldsymbol{H}$, Graphs showing changes in the content of active calpain-1 $(\boldsymbol{C}, \boldsymbol{D})$, calpain-specific cleavage product of spectrin $(\boldsymbol{E}, \boldsymbol{F})$, and $17 \mathrm{kDa}$ tau fragment $(\boldsymbol{G}, \boldsymbol{H})$ in hippocampal neurons treated with $\operatorname{ALLN}(\boldsymbol{C}, \boldsymbol{E}, \boldsymbol{G})$ or MDL 28, $170(\boldsymbol{D}, \boldsymbol{F}, \boldsymbol{H})$ before the addition of $A \beta$. Data were obtained using Molecular Analyst software and normalized using total calpain-1, spectrin, tau, and tubulin as internal controls. Values are expressed as a percentage of untreated controls, considering the values obtained in these neurons as $100 \%$. Each number represents the mean \pm SEM from three different experiments. ${ }^{*} p<0.05,{ }^{* *} p<0.01$, different from control.

Table 2. Calpain inhibitors, ALLN and MDL 28170, prevented pre-aggregated A $\beta$ induced calpain activation in cultured hippocampal neurons

\begin{tabular}{llll}
\hline & Treatment & & \\
\cline { 2 - 4 } Protease & $\mathrm{A} \beta$ & ALLN plus A $\beta$ & MDL plus A $\beta$ \\
\hline Calpain & $236 \pm 27^{*}$ & $113 \pm 17$ & $106 \pm 19$
\end{tabular}

In vitro calpain activity assays were performed using cell extracts obtained from 21-d-in-culture hippocampal neurons treated with calpain inhibitors (ALLN or MDL 28,170$) 1 \mathrm{~h}$ before the incubation with pre-aggregated A $\beta$ $(20 \mu \mathrm{m})$ for $8 \mathrm{~h}$. Values are expressed as a percentage of untreated controls, considering the values obtained in these neurons as $100 \%$. The numbers represent the means \pm SEM obtained from three experiments. ${ }^{*} p<0.01$, different from control.

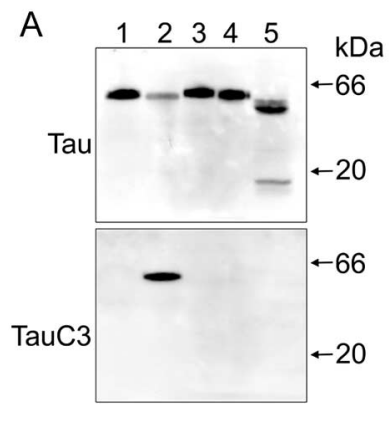

B

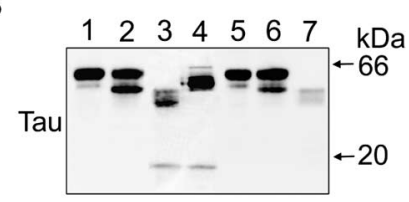

C

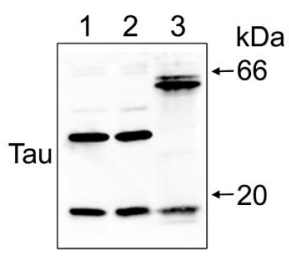

Figure 6. Calpain-1 cleaved tau in vitro, generating a $17 \mathrm{kDa}$ fragment. $A$, $\mathrm{CH} 0$ cells were transfected with tau-pRC/CMV or D421E-tau-pRC/CMV using LipofectAMINE. After $48 \mathrm{~h}$ of transfection, $\mathrm{CHO}$ cells were scraped in lysis buffer. Whole-cell lysates were incubated with buffer control or recombinant caspase- 3 at $37^{\circ} \mathrm{C}$ for $1 \mathrm{~h}$. Reaction mixtures were analyzed by immunoblot with antibodies directed against phosphorylation-independent tau (clone tau-5) or tau truncated at Asp421 by caspase-3 (clone tau-C3) antibodies. Hippocampal neurons treated with pre-aggregated $A \beta(20 \mu \mathrm{m})$ for $24 \mathrm{~h}$ were used as positive controls. Lane 1, Full-length tau with buffer control; lane 2, full-length tau with caspase-3; lane 3, D421E-tau with buffer control; lane 4, D421E-tau with caspase-3; lane 5, hippocampal neurons treated with pre-aggregated $A \beta(20 \mu \mathrm{m})$ for $24 \mathrm{~h}$. B. Full-length tau or L43A-V229A-tau-pRC/CMVtransfected $\mathrm{CHO}$ cells were harvested in lysis buffer. Whole-cell lysates were incubated with either buffer control or calpain -1 at $30^{\circ} \mathrm{C}$ for 5 or $60 \mathrm{~min}$. The reaction mixtures were analyzed by Western blot using an antibody directed against tau (clone tau-5). Hippocampal neurons treated with pre-aggregated $A \beta(20 \mu \mathrm{m})$ for $24 \mathrm{~h}$ were used as positive controls. Lane 1, Full-length tau with buffer control; lane 2, full-length tau with calpain-1 for $5 \mathrm{~min}$; lane 3, full-length tau with calpain-1 for $60 \mathrm{~min}$; lane 4, hippocampal neurons treated with preaggregated $\mathrm{A} \beta(20 \mu \mathrm{M})$ for $24 \mathrm{~h}$; lane 5, L43A-V229A-tau with buffer control; lane 6, L43AV229A-tau with calpain-1 for $5 \mathrm{~min}$; lane 7, L43A-V229A-tau with calpain-1 for $60 \mathrm{~min}$. C, Whole-cell lysates of tau45-230-pcDNA3.1 (-)-transfected CHO cells were analyzed by immunoblot reacted with an antibody against tau (clone tau-5). Tau45-230, corresponding to the 17 $\mathrm{kDa}$ fragment on tau, was incubated with either buffer control (lane 1) or calpain- 1 at $30^{\circ} \mathrm{C}$ for $1 \mathrm{~h}$ (lane 2). Hippocampal neurons treated with pre-aggregated $\mathrm{A} \beta(20 \mu \mathrm{m})$ for $24 \mathrm{~h}$ were used as positive controls (lane 3 ).
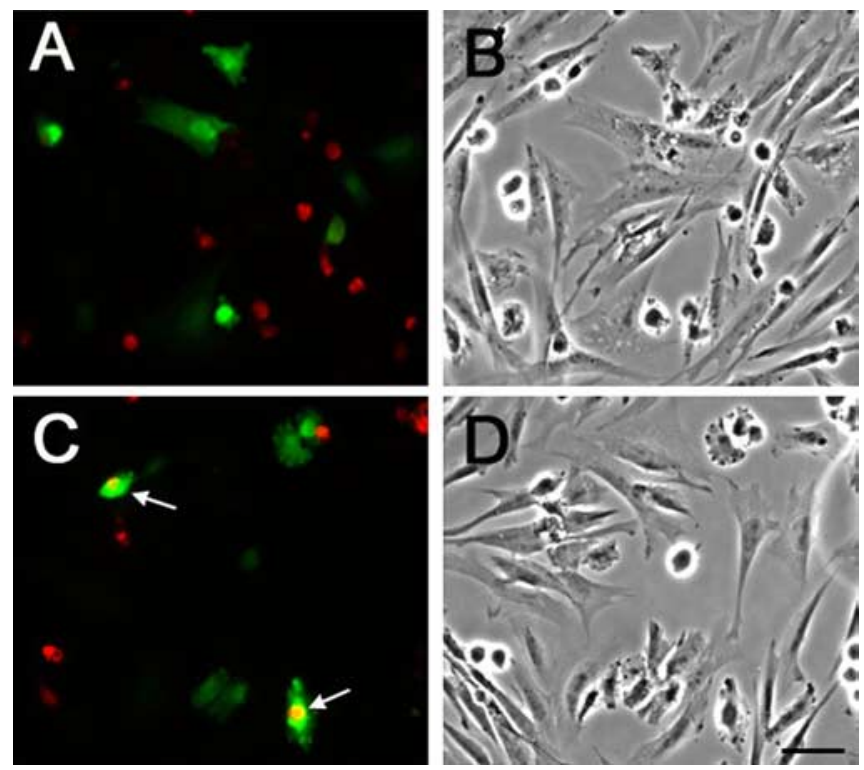

Figure 7. The $17 \mathrm{kDa}$ tau fragment induced apoptosis in $\mathrm{CHO}$ cells. $A-D$, Detection of TUNEL + cells in CHO cells transfected with GFP vector alone $(\boldsymbol{A}, \boldsymbol{B})$ or 17Tau-GFP $(\boldsymbol{C}, \boldsymbol{D})$. GFPtransfected $(\boldsymbol{A})$ and 17Tau-GFP-transfected $(\boldsymbol{C})$ cells are shown in green, and TUNEL + cells are shown in red. $\boldsymbol{B}$ and $\boldsymbol{D}$ are phase-contrast pictures of $\boldsymbol{A}$ and $\boldsymbol{C}$, respectively. Scale bar, $50 \mu \mathrm{m}$. 

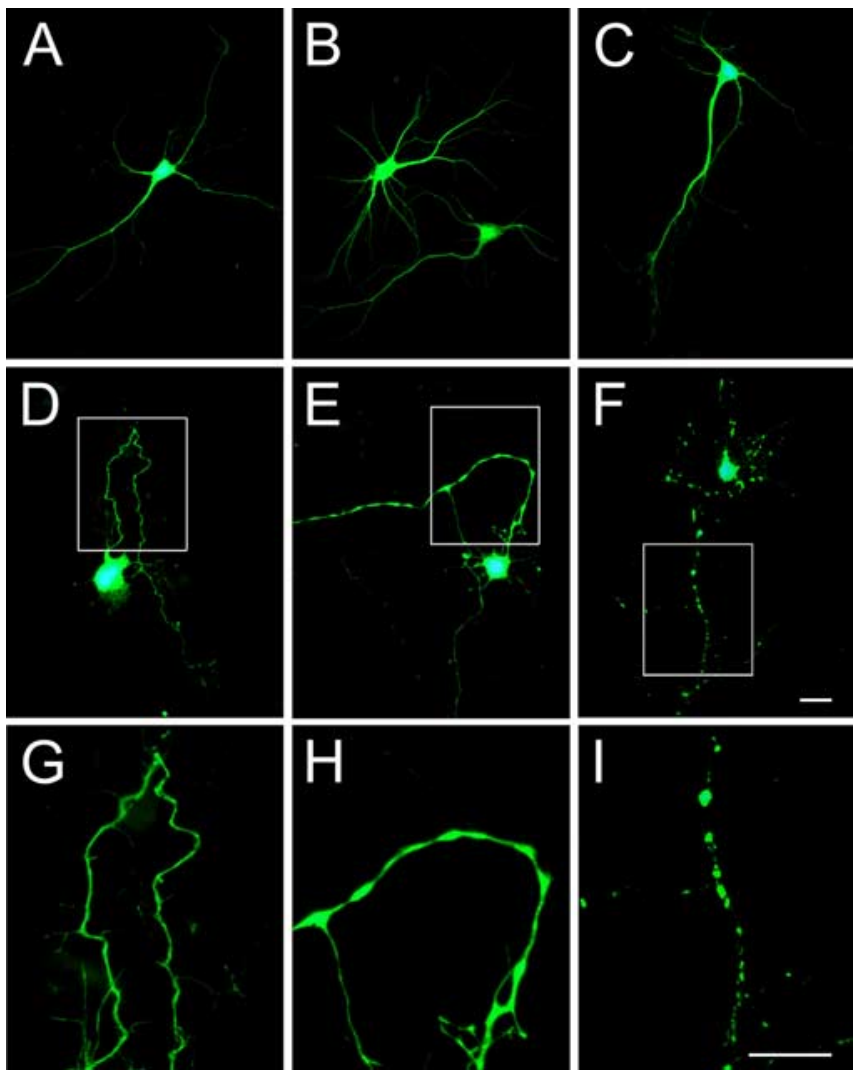

Figure 8. The $17 \mathrm{kDa}$ tau fragment induced neurodegeneration in cultured hippocampal neurons. Fourteen-day-in-culture hippocampal neurons were transfected with GFP $(\boldsymbol{A})$, fulllength Tau-GFP $(\boldsymbol{B})$, and 17Tau-GFP $(\boldsymbol{C}-\boldsymbol{I})$. GFP-transfected $(\boldsymbol{A})$ and full-length Tau-GFPtransfected $(\boldsymbol{B})$ neurons did not show any sign of degeneration even $48 \mathrm{~h}$ after transfection. Normal morphological characteristics were detected also in 17Tau-GFP-transfected cells $24 \mathrm{~h}$ after transfection (C). In contrast, hippocampal neurons transfected with 17Tau-GFP for $48 \mathrm{~h}$ showed numerous signs of degeneration, including the formation of tortuous processes $(\boldsymbol{D})$, varicosity along the neurites $(\boldsymbol{E})$, and the retraction of neurites $(\boldsymbol{F}) . \mathbf{G}-\boldsymbol{I}$, High-power magnification of the boxed areas in $\mathbf{D}-\boldsymbol{F}$. Scale bars, $20 \mu \mathrm{m}$.

way(s) activated by the deposition of $\mathrm{A} \beta$ has been investigated. Recently, we have provided direct evidence indicating that tau is essential for $\mathrm{A} \beta$-mediated neurotoxicity in hippocampal neurons (Rapoport et al., 2002). This result was built on numerous reports suggesting a key role for tau in this neurodegenerative disease. In the past, most of the studies regarding tau and the pathogenesis of $\mathrm{AD}$ have been focused on phosphorylation as a mechanism by which this microtubule-associated protein mediates $\mathrm{A} \beta$-induced toxicity. This posttranslational modification has been a tempting explanation for the role of tau in the $\mathrm{AD}$ process because of the multiple phosphorylation sites in the tau molecule, the presence of hyperphosphorylated tau as paired helical filaments in the AD brain, and the induction of tau phosphorylation in $\mathrm{A} \beta$-treated neurons (Takashima et al., 1993; Ferreira et al., 1997; Alvarez et al., 1999; Ekinci et al., 1999; Rapoport and Ferreira, 2000). More recently, it has been suggested that the proteolytic cleavage of tau also played a role in $\mathrm{AD}$. Thus, the deposition of pre-aggregated $\mathrm{A} \beta$ induced the activation of caspase- 3 and the cleavage of tau at residue 421 . Truncated tau lacking its $\mathrm{C}$-terminal 20 aa assembled more rapidly into filaments than full-length tau (Gamblin et al., 2003). These results suggested that caspase-cleaved tau might be an important downstream element in the cascade of events triggered by $\mathrm{A} \beta$.
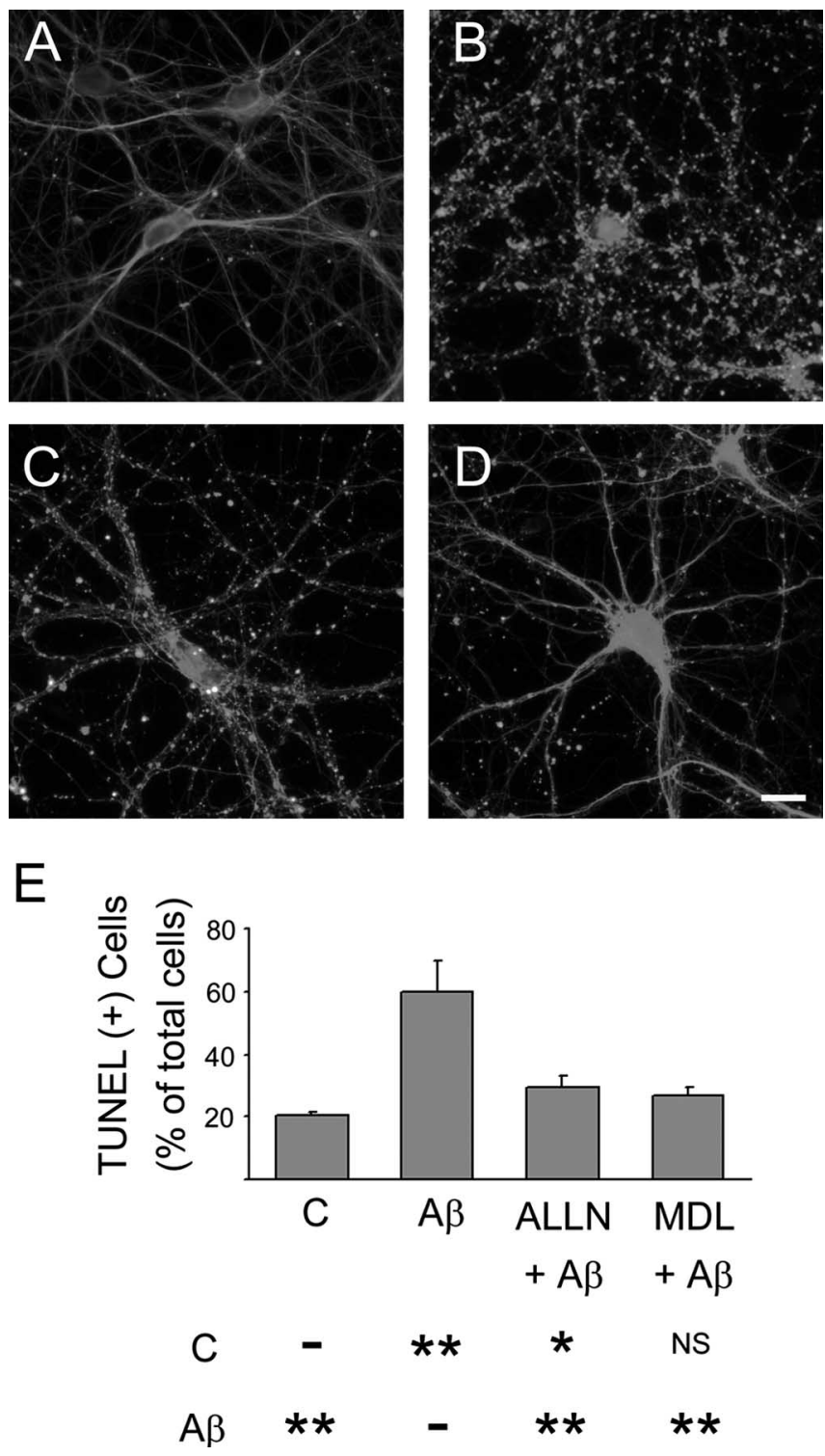

Figure 9. Calpain inhibitors prevented $A \beta$-induced neurotoxicity in culture hippocampal neurons. Hippocampal neurons cultured for $21 \mathrm{~d}$ were treated with calpain inhibitors, ALLN (C) or MDL 28, $170(\boldsymbol{D}), 1 \mathrm{~h}$ before the incubation with pre-aggregated $A \beta$ for $24 \mathrm{~h}$. No signs of neurite degeneration were detected in untreated controls $(\boldsymbol{A})$. In contrast, severe neurite degeneration was observed in cultures incubated with pre-aggregated $A \beta(B)$. Both calpain inhibitors significantly reduced the appearance of dystrophic neurites induced by $A \beta$. $\boldsymbol{E}$, Detection of TUNEL + cells in hippocampal neurons cultured in the presence or absence of calpain $(C)$ inhibitors and $A \beta$ as described above. Results were expressed as a percentage of the total number of neurons. Each number represents the mean \pm SEM from three different experiments. More than 150 neurons were counted for each experimental condition. ${ }^{*} p<0.05$, ${ }^{* *} p<0.01$, different from control. Scale bar, $20 \mu \mathrm{m}$. NS, Not statistically different.

Our results provide evidence of an alternative mechanism by which tau could mediate $\mathrm{A} \beta$-induced neurotoxicity. This mechanism involved the proteolytic cleavage of tau leading to the generation of a neurotoxic $17 \mathrm{kDa}$ tau fragment. The proteolytic cleavage of tau induced by pre-aggregated $\mathrm{A} \beta$ could lead to neurite degeneration by reducing the pool of full-length tau available for binding to microtubules. The decrease in tau bound to microtubules could in turn reduce their stability and promote a more rapid depolymerization cycle and therefore the disruption of the microtubule network. In addition, this process could lead 
to neuronal degeneration by altering the microtubule-based transport of essential materials to the distal ends of the neuronal process. Similar mechanisms have been described as a consequence of a decreased affinity of tau for microtubules resulting from its $\mathrm{A} \beta$-induced hyperphosphorylation (Gong et al., 2000; Yoshida et al., 2004). Although we cannot completely rule out the contribution of these mechanisms to $A \beta$-induced neuronal degeneration in the presence of cleaved-tau, our results support the view that the $17 \mathrm{kDa}$ tau fragment has direct toxic effects. For example, the transfection of this fragment in $\mathrm{CHO}$ cells resulted in the programmed cell death of a significant number of $17 \mathrm{kDa}$ tau-expressing cells. Furthermore, $17 \mathrm{kDa}$ tau-transfected hippocampal neurons showed signs of degeneration such as tortuous processes, the presence of varicosities along the neurites, and retraction of neuritic processes. All of these signs of degeneration were identical to the ones observed in hippocampal neurons treated with pre-aggregated A $\beta$ (Ferreira et al., 1997). The neurotoxic effects of the $17 \mathrm{kDa}$ fragment described in this study are in agreement with previous reports showing the production of other tau fragments with toxic effects under different experimental conditions in cell lines and in central neurons (Canu et al., 1998; Fasulo et al., 2000; Chung et al., 2001).

Our data also suggested that the proteolytic tau cleavage leading to the generation of the $17 \mathrm{kDa}$ fragment might be an early event in the $\mathrm{A} \beta$-induced neurodegeneration. Time-course experiments showed that the generation of the $17 \mathrm{kDa}$ tau fragment preceded tau phosphorylation in $\mathrm{A} \beta$-treated cultured neurons (Busciglio et al., 1995; Ferreira et al., 1997; Rapoport and Ferreira, 2000; Gamblin et al., 2003; present study). Although tau was truncated to the $17 \mathrm{kDa}$ fragment as early as $8 \mathrm{~h}$ after the addition of pre-aggregated $A \beta$, tau phosphorylation was significantly induced $16 \mathrm{~h}$ later.

This study provided insights into the protease(s) responsible for the generation of the $17 \mathrm{kDa}$ tau fragment in $\mathrm{A} \beta$-treated hippocampal neurons. Our experiments suggested that calpain might be involved in this tau cleavage. The activation of calpain, easily detectable $8 \mathrm{~h}$ after the addition of fibrillar $\mathrm{A} \beta$, was accompanied by a significant increase in the $17 \mathrm{kDa}$ tau fragment levels. Conversely, pretreatment with calpain inhibitors not only completely blocked the generation of the $17 \mathrm{kDa}$ tau fragment in hippocampal neurons but also prevented $\mathrm{A} \beta$-induced neurodegeneration in cultured hippocampal neurons. The role of calpain in the generation of this $17 \mathrm{kDa}$ tau fragment was confirmed by means of in vitro calpain assays. Furthermore, these experiments showed that calpain was able to cleave tau to generate a $17 \mathrm{kDa}$ fragment as a final cleavage product. These data are in agreement with previous reports suggesting that calpain could play a role in AD (Grynspan et al., 1997; Tsuji et al., 1998; Veeranna et al., 2004). Thus, it has been shown that this $\mathrm{Ca}^{2+}$-dependent protease was abnormally activated in $\mathrm{AD}$ patients compared with age-matched controls (Saito et al., 1993). In addition, active calpain-2 colocalized with tau filaments in AD, Down syndrome, and frontotemporal dementia brains (Adamec et al., 2002a,b). This close spatial association suggested the involvement of calpain in the proteolysis of this microtubule-associated protein (Adamec et al., 2002a,b). Furthermore, the similarity between tau degradation fragments present in postmortem $\mathrm{AD}$ brains and the tau breakdown products generated by calpain in vitro provides additional support for a role of this protease in tau fragmentation in human neurons affected by the AD process (Mercken et al., 1995; Yang and Ksiezak-Reding, 1995).

The mechanisms underlying the activation of calpain in $\mathrm{AD}$ are not completely elucidated. However, this increased activity has been considered a result of the massive increase in intracellular free $\mathrm{Ca}^{2+}$ concentration induced by pre-aggregated $\mathrm{A} \beta$ (Mattson et al., 1993; Lee et al., 2000; Boland and Campbell, 2003). A similar calpain activation has been obtained by experimentally inducing calcium influx into SH-SY5Y human neuroblastoma cells (Shea et al., 1996).

The data discussed above strongly suggested that calpain might be the main protease responsible for the tau cleavage leading to the generation of the $17 \mathrm{kDa}$ fragment in $\mathrm{A} \beta$-treated hippocampal neurons. However, the experiments performed using caspase- 3 inhibitors suggested that this caspase might also play a role in the generation of this fragment. A growing body of evidence suggests that caspases play a pivotal role in apoptosis induced by A $\beta$ (Ivins et al., 1998, 1999; Troy et al., 2000; Allen et al., 2001; Marques et al., 2003). Especially, caspase- 3 is considered a key component of $\mathrm{A} \beta$-induced apoptosis in cultured neurons (Harada and Sugimoto, 1999; Marin et al., 2000; Allen et al., 2001). In contrast, the activation time course of caspase- 3 in $\mathrm{A} \beta$-treated hippocampal neurons as well as caspase- 3 in vitro assays indicated that this caspase might not be directly involved in the generation of this tau fragment. Alternatively, caspases might regulate the production of this tau fragment by inducing the degradation of the endogenous calpain inhibitor calpastatin. This mechanism by which caspases could regulate calpain activity has already been reported in other systems (Wang et al., 1998). If that is the case, caspase inhibitors could reduce the degradation of calpastatin, and this in turn could inhibit the activation of calpain. This synergistic effect of calpain and caspase inhibitors has also been reported in ischemic neuronal death (Rami et al., 2000; Rami, 2003).

Collectively, our results provide insights into a novel mechanism by which tau could mediate $A \beta$-induced neurotoxicity in hippocampal neurons. They also highlight the importance of the calpain system as a target for therapeutic intervention in this neurodegenerative disease.

\section{References}

Adamec E, Mohan P, Vonsattel JP, Nixon RA (2002a) Calpain activation in neurodegenerative diseases: confocal immunofluorescence study with antibodies specifically recognizing the active form of calpain 2. Acta Neuropathol (Berl) 104:92-104.

Adamec E, Murrell JR, Takao M, Hobbs W, Nixon RA, Ghetti B, Vonsattel JP (2002b) P301L tauopathy: confocal immunofluorescence study of perinuclear aggregation of the mutated protein. J Neurol Sci 200:85-93.

Allen JW, Eldadah BA, Huang X, Knoblach SM, Faden AI (2001) Multiple caspases are involved in beta-amyloid-induced neuronal apoptosis. J Neurosci Res 65:45-53.

Alvarez A, Toro R, Caceres A, Maccioni RB (1999) Inhibition of tau phosphorylating protein kinase cdk5 prevents beta-amyloid-induced neuronal death. FEBS Lett 459:421-426.

Bensadoun A, Weinstein D (1976) Assay of proteins in the presence of interfering materials. Anal Biochem 70:241-250.

Boland B, Campbell V (2003) Beta-amyloid (1-40)-induced apoptosis of cultured cortical neurones involves calpain-mediated cleavage of polyADP-ribose polymerase. Neurobiol Aging 24:179-186.

Bottenstein JE, Sato GH (1979) Growth of a rat neuroblastoma cell line in serum-free supplemented medium. Proc Natl Acad Sci USA 76:514-517.

Brancolini C, Lazarevic D, Rodriguez J, Schneider C (1997) Dismantling cell-cell contacts during apoptosis is coupled to a caspase-dependent proteolytic cleavage of beta-catenin. J Cell Biol 139:759-771.

Busciglio J, Lorenzo A, Yeh J, Yankner BA (1995) Beta-amyloid fibrils induce tau phosphorylation and loss of microtubule binding. Neuron 14:879-888.

Canevari L, Abramov AY, Duchen MR (2004) Toxicity of amyloid beta peptide: tales of calcium, mitochondria, and oxidative stress. Neurochem Res 29:637-650.

Canu N, Dus L, Barbato C, Ciotti MT, Brancolini C, Rinaldi AM, Novak M, 
Cattaneo A, Bradbury A, Calissano P (1998) Tau cleavage and dephosphorylation in cerebellar granule neurons undergoing apoptosis. J Neurosci 18:7061-7074.

Chung CW, Song YH, Kim IK, Yoon WJ, Ryu BR, Jo DG, Woo HN, Kwon YK, Kim HH, Gwag BJ, Mook-Jung IH, Jung YK (2001) Proapoptotic effects of tau cleavage product generated by caspase-3. Neurobiol Dis 8:162-172.

Copani A, Bruno V, Battaglia G, Leanza G, Pellitteri R, Russo A, Stanzani S, Nicoletti F (1995) Activation of metabotropic glutamate receptors protects cultured neurons against apoptosis induced by beta-amyloid peptide. Mol Pharmacol 47:890-897.

Ekinci FJ, Malik KU, Shea TB (1999) Activation of the L voltage-sensitive calcium channel by mitogen-activated protein (MAP) kinase following exposure of neuronal cells to beta-amyloid. MAP kinase mediates betaamyloid-induced neurodegeneration. J Biol Chem 274:30322-30327.

Estus S, Tucker HM, van Rooyen C, Wright S, Brigham EF, Wogulis M, Rydel RE (1997) Aggregated amyloid-beta protein induces cortical neuronal apoptosis and concomitant "apoptotic" pattern of gene induction. J Neurosci 17:7736-7745.

Fasulo L, Ugolini G, Visintin M, Bradbury A, Brancolini C, Verzillo V, Novak M, Cattaneo A (2000) The neuronal microtubule-associated protein tau is a substrate for caspase-3 and an effector of apoptosis. J Neurochem 75:624-633.

Ferreira A, Busciglio J, Caceres A (1989) Microtubule formation and neurite growth in cerebellar macroneurons which develop in vitro: evidence for the involvement of the microtubule-associated proteins, MAP-1a, HMW-MAP2 and Tau. Brain Res Dev Brain Res 49:215-228.

Ferreira A, Lu Q, Orecchio L, Kosik KS (1997) Selective phosphorylation of adult tau isoforms in mature hippocampal neurons exposed to fibrillar A beta. Mol Cell Neurosci 9:220-234.

Flood JF, Morley JE, Roberts E (1991) Amnestic effects in mice of four synthetic peptides homologous to amyloid beta protein from patients with Alzheimer disease. Proc Natl Acad Sci USA 88:3363-3366.

Gamblin TC, Chen F, Zambrano A, Abraha A, Lagalwar S, Guillozet AL, Lu M, Fu Y, Garcia-Sierra F, LaPointe N, Miller R, Berry RW, Binder LI, Cryns VL (2003) Caspase cleavage of tau: linking amyloid and neurofibrillary tangles in Alzheimer's disease. Proc Natl Acad Sci USA 100:10032-10037.

Glenner GG, Wong CW (1984) Alzheimer's disease: initial report of the purification and characterization of a novel cerebrovascular amyloid protein. Biochem Biophys Res Commun 120:885-890.

Gong CX, Lidsky T, Wegiel J, Zuck L, Grundke-Iqbal I, Iqbal K (2000) Phosphorylation of microtubule-associated protein tau is regulated by protein phosphatase $2 \mathrm{~A}$ in mammalian brain. Implications for neurofibrillary degeneration in Alzheimer's disease. J Biol Chem 275:5535-5544.

Goslin K, Banker G (1990) Rapid changes in the distribution of GAP-43 correlate with the expression of neuronal polarity during normal development and under experimental conditions. J Cell Biol 110:1319-1331.

Grynspan F, Griffin WR, Cataldo A, Katayama S, Nixon RA (1997) Active site-directed antibodies identify calpain II as an early-appearing and pervasive component of neurofibrillary pathology in Alzheimer's disease. Brain Res 763:145-158.

Harada J, Sugimoto M (1999) Activation of caspase-3 in beta-amyloidinduced apoptosis of cultured rat cortical neurons. Brain Res 842:311-323.

Imajoh S, Kawasaki H, Suzuki K (1987) The COOH-terminal E-F hand structure of calcium-activated neutral protease (CANP) is important for the association of subunits and resulting proteolytic activity. J Biochem (Tokyo) 101:447-452.

Ivins KJ, Bui ET, Cotman CW (1998) Beta-amyloid induces local neurite degeneration in cultured hippocampal neurons: evidence for neuritic apoptosis. Neurobiol Dis 5:365-378.

Ivins KJ, Thornton PL, Rohn TT, Cotman CW (1999) Neuronal apoptosis induced by beta-amyloid is mediated by caspase- 8 . Neurobiol Dis 6:440-449.

Kondo J, Honda T, Mori H, Hamada Y, Miura R, Ogawara M, Ihara Y (1988) The carboxyl third of tau is tightly bound to paired helical filaments. Neuron 1:827-834.

Kosik KS, Joachim CL, Selkoe DJ (1986) Microtubule-associated protein tau (tau) is a major antigenic component of paired helical filaments in Alzheimer disease. Proc Natl Acad Sci USA 83:4044-4048.

Laemmli UK (1970) Cleavage of structural proteins during the assembly of the head of bacteriophage T4. Nature 227:680-685.
Lee MS, Kwon YT, Li M, Peng J, Friedlander RM, Tsai LH (2000) Neurotoxicity induces cleavage of $\mathrm{p} 35$ to $\mathrm{p} 25$ by calpain. Nature 405:360-364.

LoPresti P, Szuchet S, Papasozomenos SC, Zinkowski RP, Binder LI (1995) Functional implications for the microtubule-associated protein tau: localization in oligodendrocytes. Proc Natl Acad Sci USA 92:10369-10373.

Lowry OH, Rosebrough NJ, Farr AL, Randall RJ (1951) Protein measurement with the Folin phenol reagent. J Biol Chem 193:265-275.

Marin N, Romero B, Bosch-Morell F, Llansola M, Felipo V, Roma J, Romero FJ (2000) Beta-amyloid-induced activation of caspase- 3 in primary cultures of rat neurons. Mech Ageing Dev 119:63-67.

Marques CA, Keil U, Bonert A, Steiner B, Haass C, Muller WE, Eckert A (2003) Neurotoxic mechanisms caused by the Alzheimer's diseaselinked Swedish amyloid precursor protein mutation: oxidative stress, caspases, and the JNK pathway. J Biol Chem 278:28294-28302.

Mattson MP, Tomaselli KJ, Rydel RE (1993) Calcium-destabilizing and neurodegenerative effects of aggregated beta-amyloid peptide are attenuated by basic FGF. Brain Res 621:35-49.

Mellgren RL, Murachi T (1990) Intracellular calcium-dependent proteolysis. Boca Raton, FL: CRC.

Mercken M, Grynspan F, Nixon RA (1995) Differential sensitivity to proteolysis by brain calpain of adult human tau, fetal human tau and PHF-tau. FEBS Lett 368:10-14.

Nitta A, Itoh A, Hasegawa T, Nabeshima T (1994) Beta-amyloid proteininduced Alzheimer's disease animal model. Neurosci Lett 170:63-66.

Novak M, Kabat J, Wischik CM (1993) Molecular characterization of the minimal protease resistant tau unit of the Alzheimer's disease paired helical filament. EMBO J 12:365-370.

Rami A (2003) Ischemic neuronal death in the rat hippocampus: the calpain-calpastatin-caspase hypothesis. Neurobiol Dis 13:75-88.

Rami A, Agarwal R, Botez G, Winckler J (2000) mu-Calpain activation, DNA fragmentation, and synergistic effects of caspase and calpain inhibitors in protecting hippocampal neurons from ischemic damage. Brain Res 866:299-312.

Rapoport M, Ferreira A (2000) PD98059 prevents neurite degeneration induced by fibrillar beta-amyloid in mature hippocampal neurons. J Neurochem 74:125-133.

Rapoport M, Dawson HN, Binder LI, Vitek MP, Ferreira A (2002) Tau is essential to beta -amyloid-induced neurotoxicity. Proc Natl Acad Sci USA 99:6364-6369.

Rohn TT, Head E, Su JH, Anderson AJ, Bahr BA, Cotman CW, Cribbs DH (2001) Correlation between caspase activation and neurofibrillary tangle formation in Alzheimer's disease. Am J Pathol 158:189-198.

Saito K, Elce JS, Hamos JE, Nixon RA (1993) Widespread activation of calcium-activated neutral proteinase (calpain) in the brain in Alzheimer disease: a potential molecular basis for neuronal degeneration. Proc Natl Acad Sci USA 90:2628-2632.

Selkoe DJ (1994) Cell biology of the amyloid beta-protein precursor and the mechanism of Alzheimer's disease. Annu Rev Cell Biol 10:373-403.

Shea TB, Spencer MJ, Beermann ML, Cressman CM, Nixon RA (1996) Calcium influx into human neuroblastoma cells induces ALZ-50 immunoreactivity: involvement of calpain-mediated hydrolysis of protein kinase C. J Neurochem 66:1539-1549.

Su JH, Zhao M, Anderson AJ, Srinivasan A, Cotman CW (2001) Activated caspase- 3 expression in Alzheimer's and aged control brain: correlation with Alzheimer pathology. Brain Res 898:350-357.

Szendrei GI, Lee VM, Otvos Jr L (1993) Recognition of the minimal epitope of monoclonal antibody Tau- 1 depends upon the presence of a phosphate group but not its location. J Neurosci Res 34:243-249.

Takashima A, Noguchi K, Sato K, Hoshino T, Imahori K (1993) Tau protein kinase I is essential for amyloid beta-protein-induced neurotoxicity. Proc Natl Acad Sci USA 90:7789-7793.

Towbin H, Staehelin T, Gordon J (1979) Electrophoretic transfer of proteins from polyacrylamide gels to nitrocellulose sheets: procedure and some applications. Proc Natl Acad Sci USA 76:4350-4354.

Troy CM, Rabacchi SA, Friedman WJ, Frappier TF, Brown K, Shelanski ML (2000) Caspase- 2 mediates neuronal cell death induced by $\beta$-amyloid. J Neurosci 20:1386-1392.

Tsuji T, Shimohama S, Kimura J, Shimizu K (1998) m-Calpain (calciumactivated neutral proteinase) in Alzheimer's disease brains. Neurosci Lett 248:109-112.

Veeranna, Kaji T, Boland B, Odrljin T, Mohan P, Basavarajappa BS, Peterhoff C, Cataldo A, Rudnicki A, Amin N, Li BS, Pant HC, Hungund BL, Arancio 
O, Nixon RA (2004) Calpain mediates calcium-induced activation of the erk1,2 MAPK pathway and cytoskeletal phosphorylation in neurons: relevance to Alzheimer's disease. Am J Pathol 165:795-805.

Wang KK, Posmantur R, Nadimpalli R, Nath R, Mohan P, Nixon RA, Talanian RV, Keegan M, Herzog L, Allen H (1998) Caspase-mediated fragmentation of calpain inhibitor protein calpastatin during apoptosis. Arch Biochem Biophys 356:187-196.

Wood JG, Mirra SS, Pollock NJ, Binder LI (1986) Neurofibrillary tangles of Alzheimer disease share antigenic determinants with the axonal microtubule-associated protein tau (tau). Proc Natl Acad Sci USA 83:4040-4043.
Yang LS, Ksiezak-Reding H (1995) Calpain-induced proteolysis of normal human tau and tau associated with paired helical filaments. Eur J Biochem 233:9-17.

Yankner BA, Mesulam MM (1991) Seminars in medicine of the Beth Israel Hospital, Boston. Beta-amyloid and the pathogenesis of Alzheimer's disease. N Engl J Med 325:1849-1857.

Yoshida H, Hastie CJ, McLauchlan H, Cohen P, Goedert M (2004) Phosphorylation of microtubule-associated protein tau by isoforms of c-Jun N-terminal kinase (JNK). J Neurochem 90:352-358.

Zimmerman UP, Schlaepfer WW (1984) Multiple forms of Ca-activated protease from rat brain and muscle. J Biol Chem 259:3210-3218. 